\title{
Application of Influence Lines on Static Analysis of Cable-Stayed Bridges
}

\author{
F. Masoumi and A. Mehrabzadeh
}

\begin{abstract}
Cable stayed bridges are one of the most advanced bridges ever built. This type of bridges geometrically is similar to suspension bridges, but their structural behaviors are so different. In the last decade for bridges with span length $(500-1000 \mathrm{~m})$, the cable stayed bridges have been more welcomed. In comparison with suspension bridges, the cable stayed bridges have advantages like the simple construction of foundations. In this paper, for a specific cable stayed bridge three different connection systems including radial, harp and fan are designed and modeled by finite-element software (ANSYS). Based on the results of static analysis of bridges, the elements which have the maximum internal forces are chosen. The influence lines of shear force, axial force of cables and bending moments of selected elements are drawn for three bridge types. The results indicate that, for bridges subjected to high concentrated loads, bridges with radial and fan cables have better structural performance and for bridges subjected to high distributed loads, bridges with harp cables have better performance than the others.
\end{abstract}

Index Terms - Cable-stayed bridge, influence line, ANSYS

\section{INTRODUCTION}

In recent years, due to rapid advances in technology and human needs for better and faster communication with other parts of the world, bridges play an important role in human life [1]. Because of their attractive appearance civil engineers are more interested in cable-stayed bridges and nowadays, these types of bridges are constructed more than last decades [2]. In modern cable stayed bridges, main span lengths are increased, and shallower girders are used. Since, the structural safety of these bridges under service loadings and environmental dynamic loadings should be investigated [3]. In this paper, for Owensboro cable-stayed bridge, three different connection systems including radial, harp and fan are suggested and for designed bridges the application of influence lines on static analysis of bridges is investigated [4], [5].

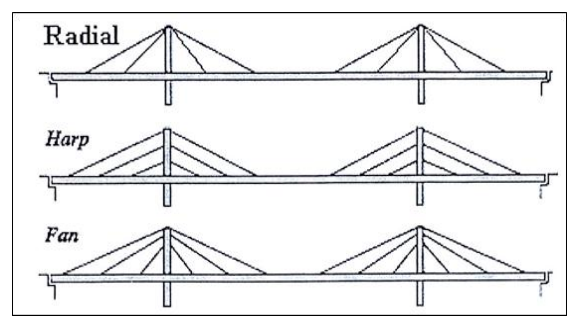

Fig. 1. Three connection systems of cables in cable-stayed bridges

Manuscript received March 16, 2013; revised July 5, 2013.

The authors are with the Civil Engineering from Azerbaijan University of Tarbiat Moallem, Iran (e-mail: alvandme@gmail.com).

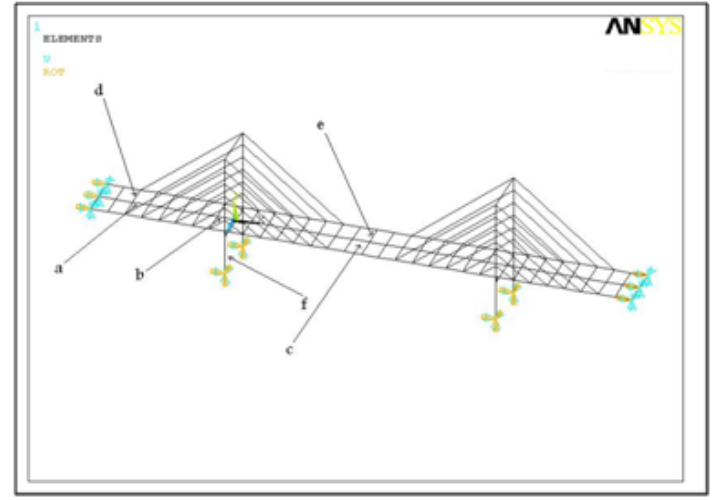

Fig. 2. Seleceted elements of bridges

\section{APPLICATION OF INFLUENCE LINES ON STATIC ANALYSIS OF CABLE-STAYED BRIDGES}

Three cable-stayed bridges with different connection systems including radial, harp and fan are designed and modeled by finite element software ANSYS. The static analysis of bridges is done, and elements with maximum shear force and bending moment are determined. As shown in Fig. 2, in elements a, $\mathrm{d}$ and $\mathrm{f}$ the shear force and bending moment are maximum, and the maximum deflection of the bridge is related to elements e and $c$. The influence line of shear force and bending moment for elements a, b, c, d, e and $f$ are plotted and these graphs were used for determining the maximum shear force and bending moment which can be imposed by concentrated and distributed loads. The influence line of bending moment for critical elements of cable-stayed bridges with harp cables are shown in Fig. 3. The area between influence line and horizontal axes can be used for estimation of load length of each element. The positive area indicates that a distributed load with a positive sign can impose maximum bending moment and vice versa. The areas between influence line of bending moment and horizontal axes of critical elements are shown in Table I. As shown in Table I, cable-stayed bridge with radial cables has maximum area and the minimum area is related to fan cables. Two different cases are considered, in the first one all over the deck of the bridge is loaded with live load and in second one, based on the results of influence lines, partial loading is done on the deck, and the results are shown in Table II. For elements which there are not changing of sign of influence line, both cases will yield the same results. It is obvious in Table II that the bending moment of the second case is much more than case 1 , and it shows the advantages of using 
influence line on static behavior of a structure.

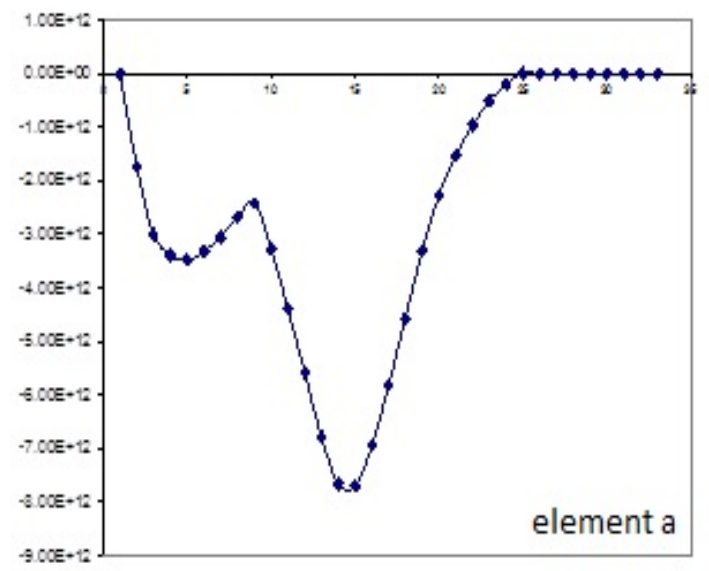

(a)

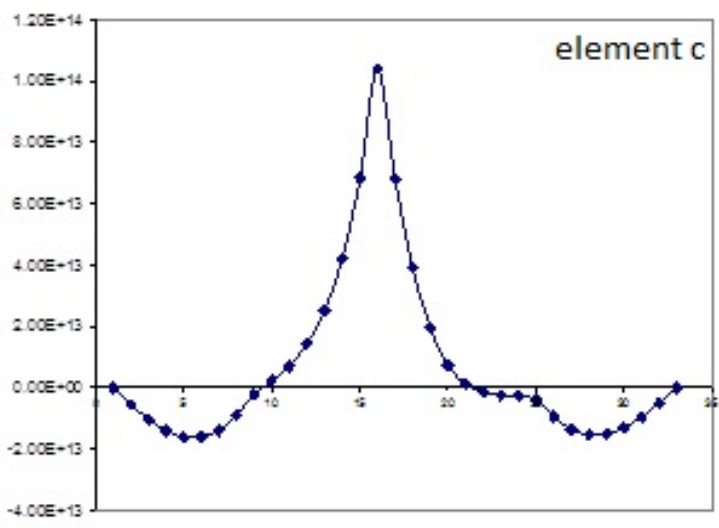

(c)

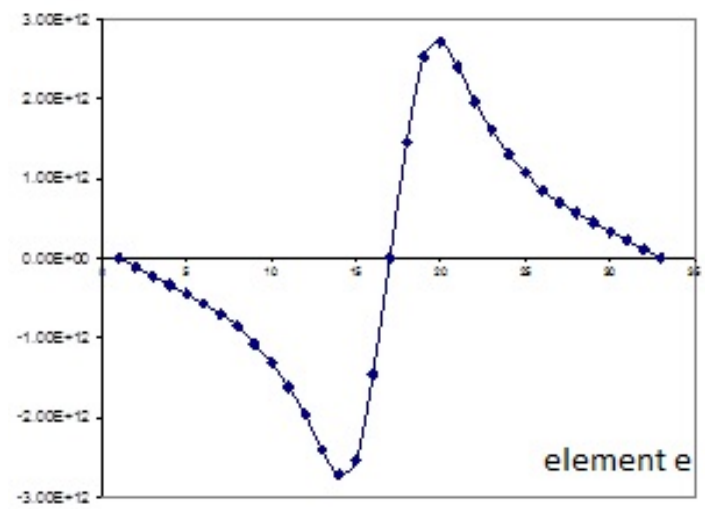

(e)

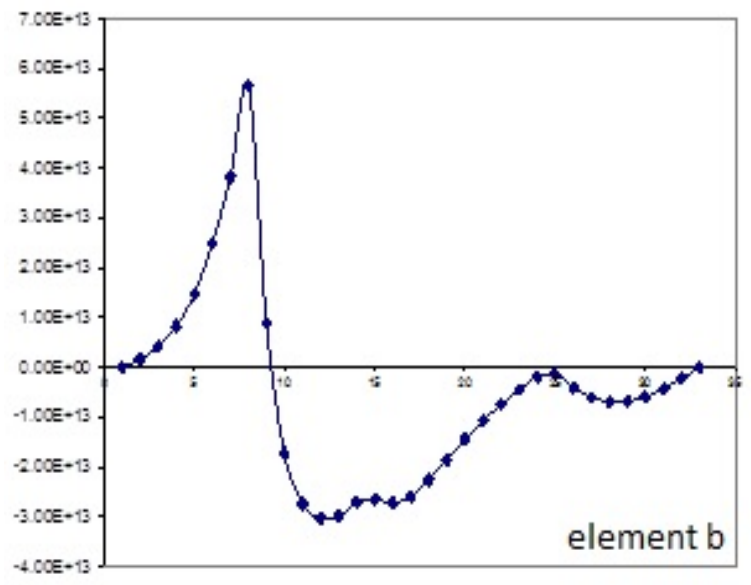

(b)



(d)

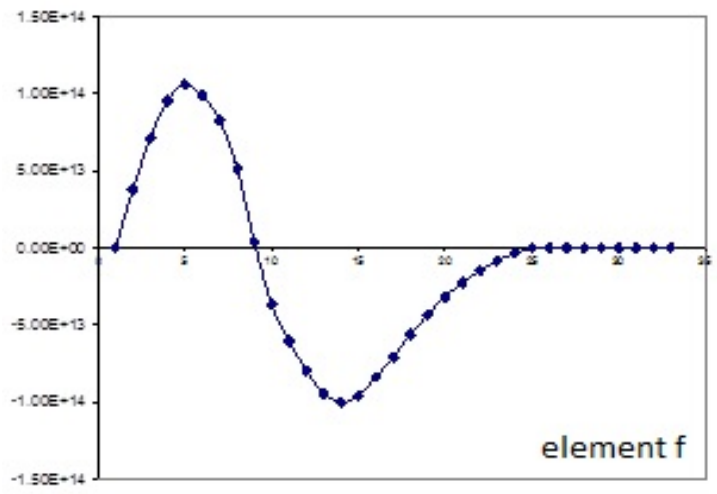

(f)

Fig 3. Influence line of bending moment for critical elements of bridge with harp cables

The influence line of shear force for critical elements of cable-stayed bridges with harp cables are shown in Fig. 4. The areas between influence line of shear force and horizontal axes of critical elements are shown In Table III. As shown in Table III, cable-stayed bridge with radial cables has maximum area and the minimum area is related to harp cables. The influence line of axial force for critical cables of cable-stayed bridges with harp cables are shown in Fig. 5. The areas between influence line of axial force and horizontal axes of critical cable are shown in Table IV.
TABLE I: AREA BETwEEN INFLUENCE LINE OF BENDING MOMENT AND HORIZONTAL AXES OF CRITICAL ELEMENTS

\begin{tabular}{lllllll}
\hline \hline & $\begin{array}{l}\text { Positive } \\
\text { area } \\
\text { element }\end{array}$ & $\begin{array}{l}\text { Negative } \\
\text { area } \\
\text { (harp) }\end{array}$ & $\begin{array}{l}\text { Positive } \\
\text { area } \\
\text { (fan) }\end{array}$ & $\begin{array}{l}\text { Negative } \\
\text { area } \\
\text { (fan) }\end{array}$ & $\begin{array}{l}\text { Positive } \\
\text { area } \\
\text { (radial) }\end{array}$ & $\begin{array}{l}\text { Negative } \\
\text { area } \\
\text { (radial) }\end{array}$ \\
\hline a & 0 & 1392.7 & 0 & 1377 & 0 & 1533.04 \\
b & 232 & 504.55 & 174.4 & 457.91 & 250.48 & 520 \\
c & 419.52 & 189.9 & 409.3 & 184.4 & 436 & 201.5 \\
d & 1512.5 & 0 & 1479 & 0 & 1515 & 0 \\
e & 502.73 & 498.92 & 481.87 & 476.08 & 507.84 & 508.67 \\
$\mathrm{f}$ & 400 & 460.86 & 394.55 & 451.3 & 404.92 & 440.64 \\
\hline \hline
\end{tabular}


IACSIT International Journal of Engineering and Technology, Vol. 5, No. 6, December 2013

TABLE II: BENDING MOMENTS OF TwO DIFFERENT CASES

\begin{tabular}{|c|c|c|}
\hline \multirow{2}{*}{ element } & Bending moment of case 1 & Bending moment of case 2 \\
\hline b & $-0.1859 \mathrm{e}+8$ & $-0.3138 \mathrm{e}+8$ \\
\hline $\mathrm{c}$ & $-0.3611 \mathrm{e}+8$ & $-0.5412 \mathrm{e}+8$ \\
\hline $\mathrm{e}$ & $-0.1439 \mathrm{e}+6$ & $-0.6669 \mathrm{e}+6$ \\
\hline $\mathrm{f}$ & $0.1724 \mathrm{e}+9$ & $0.2568 \mathrm{e}+9$ \\
\hline
\end{tabular}

TABLE III: AREA BETWEEN INFLUENCE LINE OF SHEAR FORCE AND HORIZONTAL AXES OF CRITICAL ELEMENTS

\begin{tabular}{|c|c|c|c|c|c|c|}
\hline element & $\begin{array}{c}\text { Positive area } \\
\text { (harp) }\end{array}$ & $\begin{array}{c}\text { Negative } \\
\text { area } \\
\text { (harp) }\end{array}$ & $\begin{array}{c}\text { Positive area } \\
\text { (fan) }\end{array}$ & $\begin{array}{c}\text { Negative } \\
\text { area } \\
\text { (fan) }\end{array}$ & $\begin{array}{c}\text { Positive area } \\
\text { (radial) }\end{array}$ & $\begin{array}{c}\text { Negative } \\
\text { area } \\
\text { (radial) }\end{array}$ \\
\hline a & 140.71 & 370.57 & 144.54 & 386 & 147.82 & 386 \\
\hline b & 207.23 & 227.95 & 223.23 & 243.23 & 194.48 & 228.47 \\
\hline c & 207.36 & 236.27 & 213.21 & 242.45 & 218 & 248.48 \\
\hline d & 24.68 & 119.55 & 32.85 & 129.43 & 32.32 & 138.1 \\
\hline e & 71.9 & 120.86 & 75.3 & 121.05 & 77.45 & 124.46 \\
\hline f & 0 & 1510.53 & 0 & 1583.5 & 0 & 1620.73 \\
\hline
\end{tabular}

TABLE IV: AREA BETWEEN INFLUENCE LINE OF AXIAL FORCE AND HORIZONTAL AXES OF CRITICAL CABLES

\begin{tabular}{|c|c|c|c|c|c|c|}
\hline cable & $\begin{array}{c}\text { Positive } \\
\text { area } \\
\text { (harp) }\end{array}$ & $\begin{array}{c}\text { Negative } \\
\text { area } \\
\text { (harp) }\end{array}$ & $\begin{array}{c}\text { Positive } \\
\text { area } \\
\text { (fan) }\end{array}$ & $\begin{array}{c}\text { Negative } \\
\text { area } \\
\text { (fan) }\end{array}$ & $\begin{array}{c}\text { Positive } \\
\text { area } \\
\text { (radial) }\end{array}$ & $\begin{array}{c}\text { Negative } \\
\text { area } \\
\text { (radial) }\end{array}$ \\
\hline $\mathrm{g}$ & 540.35 & 0 & 551.66 & 0 & 615.22 & 0 \\
\hline $\mathrm{h}$ & 531.13 & 0 & 542.62 & 0 & 566.16 & 0 \\
\hline $\mathrm{i}$ & 756.68 & 0 & 764.24 & 0 & 779.41 & 0 \\
\hline $\mathrm{j}$ & 557.98 & 0 & 720.64 & 0 & 756.15 & 0 \\
\hline $\mathrm{k}$ & 340.29 & 0 & 359.39 & 0 & 381.43 & 0 \\
\hline
\end{tabular}

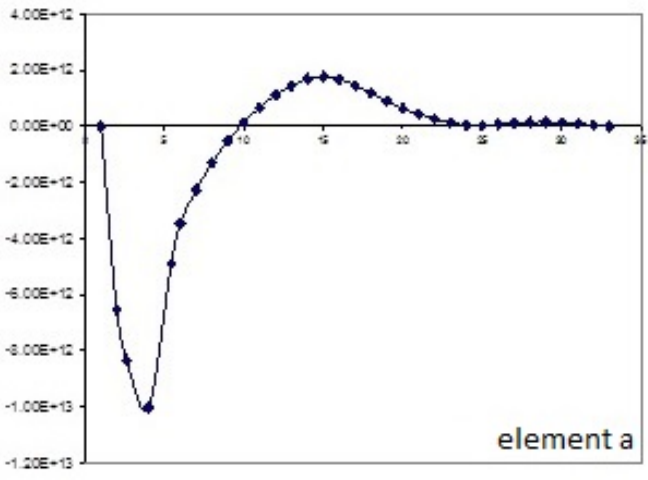

(a)

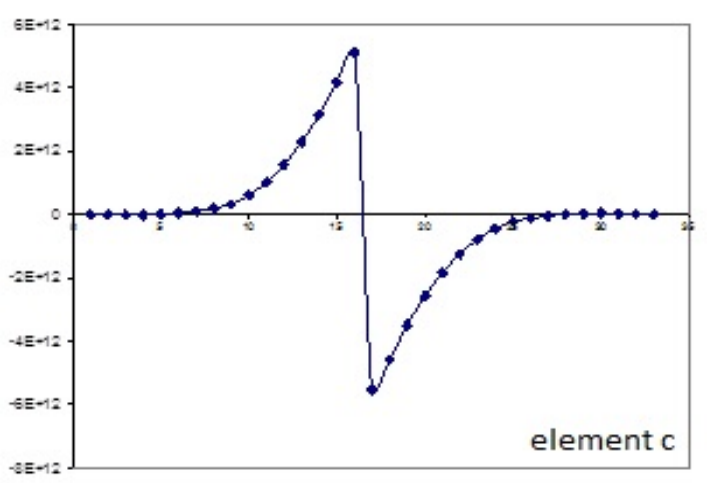

(c)

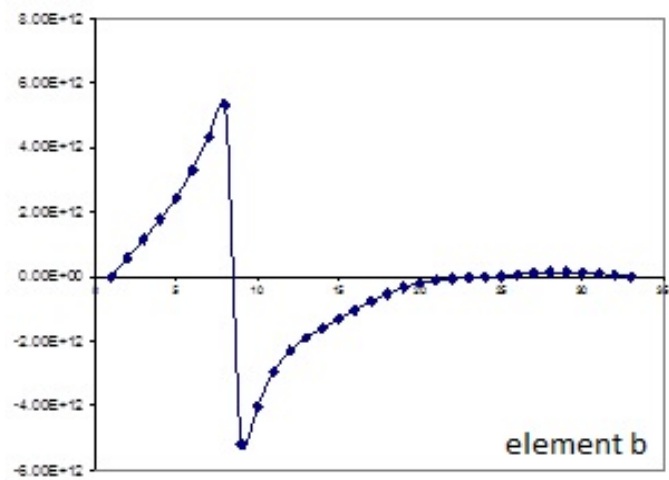

(b)

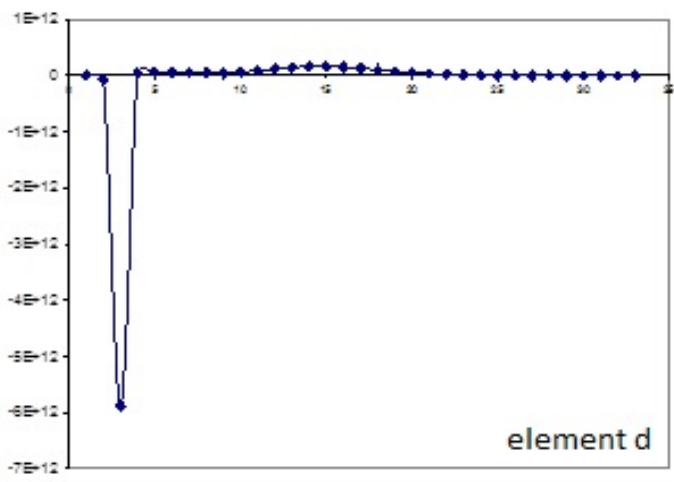

(d) 


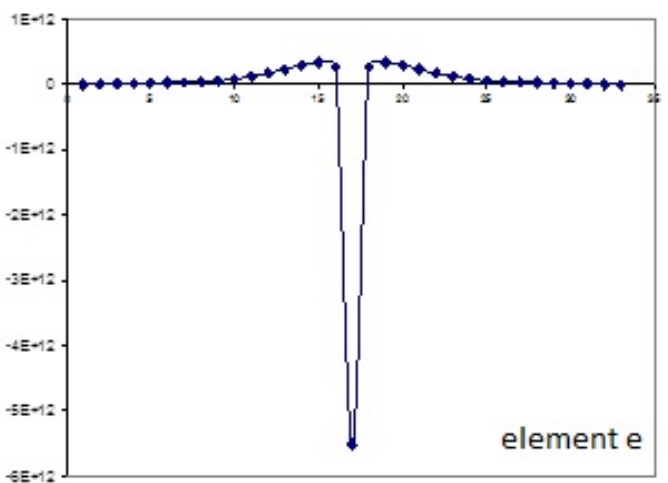

(e)



(f)

Fig. 4. Influence line of shear force for critical elements of bridge with harp cables

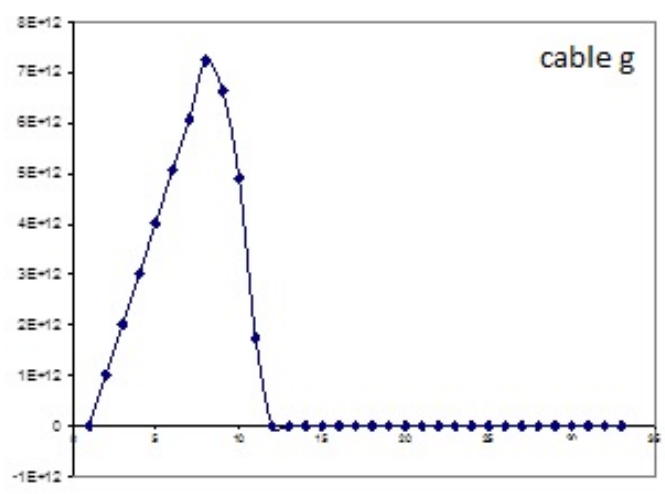

(a)

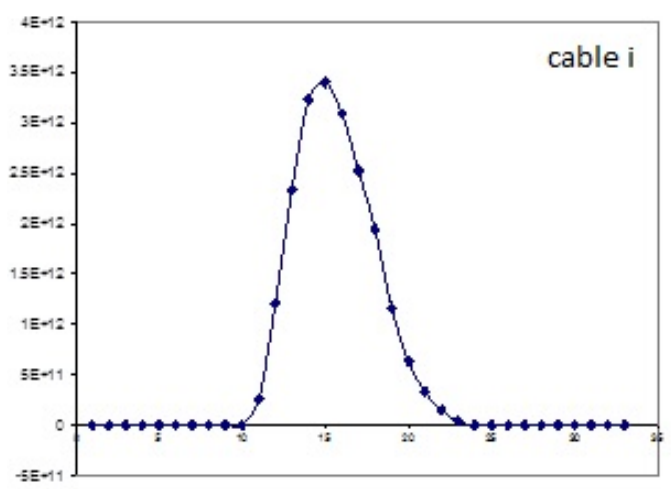

(c)

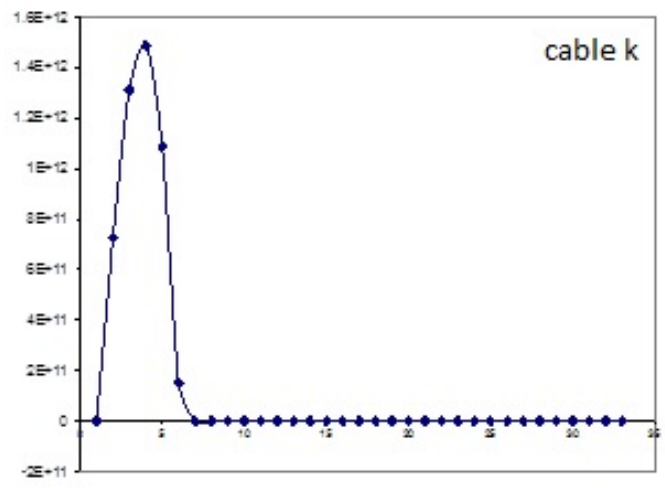

(e)

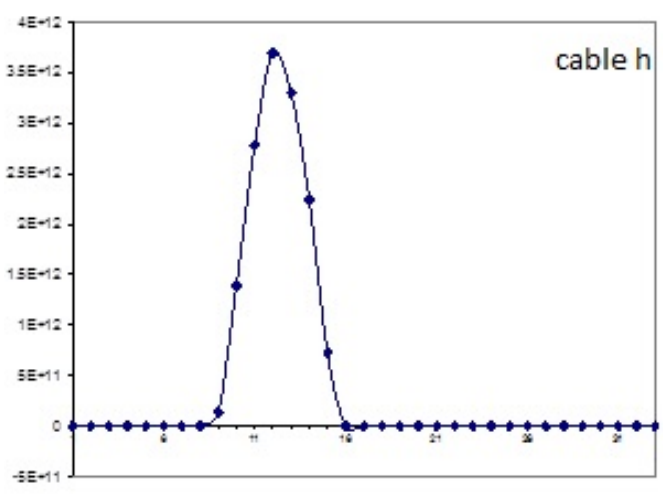

(b)

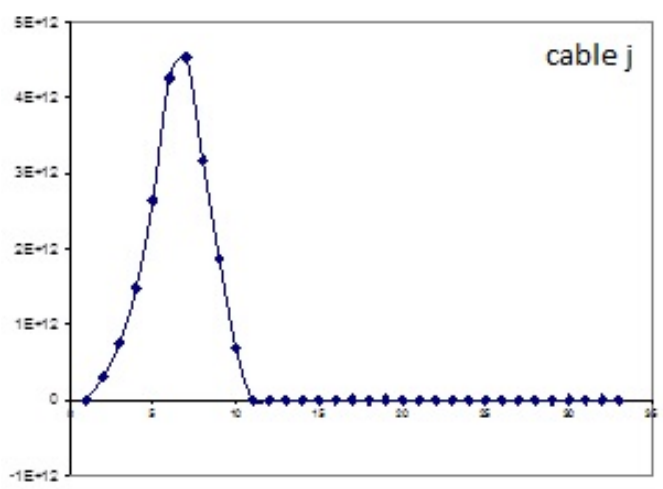

(d)

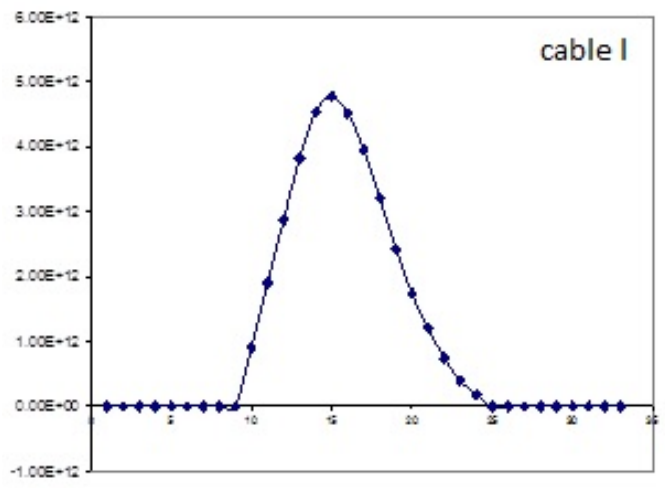

(f)

Fig 5. Influence line of axial force for critical cables of cable-stayed bridges with harp cables

As shown in Table IV, bridges with radial cables have the maximum area and minimum area is related to harp cables.

\section{CONCLUSION}

In this paper, cable stayed bridges with different connection systems are investigated. The influence lines of shear force and bending moment for critical elements and influence line of axial force for critical cables are plotted, and their maximum amounts and also the area between influence lines and horizontal axes are estimated. The results indicate that for longitudinal beams on the deck, the maximum shear 
force is related to harp cables, and for transverse beam elements,maximum shear force is related to fan cables. The harp cables have maximum axial force of cables and for all beam elements including longitudinal and transverse, bridges with harp cables have approximately $10 \%$ more bending moment. As a result, the maximum amount of influence lines of shear force, bending moment and axial force of cables are related to harp system and minimum amounts are related to fan system. It means that for concentrated loads, a bridge with fan connection system is better than two other systems. The maximum area of influence line is related to radial system, and the minimum area is related to harp system, and it means that for distributed loads, a bridge with concoction system of harp is better than two other systems.

\section{REFERENCES}

[1] M. D. Papin and A. Kaufmann, Cours de calcul operationaael appliqué, Ed. Albin Michel, Paris, 1963

[2] F. Casciati, G. P. Cimellaro, and M. Domaneschi, "Seismic reliability of a cable-stayed bridge retrofitted with hysteretic devices Comput Struct," Earthquake Engineering and Engineering Vibration, vol. 28 , pp. 1769-1781, 2008
[3] M. Virlogeus "Recent evolution of cable stayed bridges," Journal of engineering structures, vol. 21, 1999, pp. 737-755.

[4] F. Masoumi, "The Effect of Specification Variations of Cables on Dynamic Response of Cable-Stayed Bridges," M.S. thesis, Dept. Civil. Eng., Islamic Azad Univ., Iran, 2005.

[5] P. H. Wang, T. C. Tseng, and C. G. Yang. "Initial shape of cable-stayed bridges," J Comput Struct, vol. 46, 1993, pp. 1095-1106

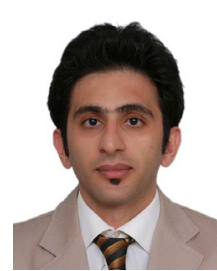

F. Masoumi received his B.S. degree in Civil Engineering from Azerbaijan University of Tarbiat Moallem, Iran, in 2005 and M.S. in Civil Engineering, Structure from Islamic Azad University, Maragheh Branch, in 2007. He is currently Ph.D. Candidate in METU

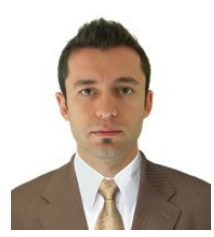

A. Mehrabzadeh received his B.S. degree in Civil Engineering from Ardebil University, Ardebil, Iran, in 2005. He will receive his M.S. degree in 2013, Middle East Technical University, Ankara, Turkey. His research interests are in the areas of Structural Health Monitoring and Bridge Engineering with emphasis on non-destructive bridge evaluation and condition assessment. 